\title{
A outridade em Paulo Leminski
}

\author{
The other in Paulo Leminski
}

La alteridad en Paulo Leminski

Adriane Cherpinski ${ }^{1}$

Evely Vânia Libanori® 1

1Universidade Estadual de Maringá, Maringá, Paraná, Brasil.

\begin{abstract}
RESUMO
Recortes poéticos da obra $O$ ex-estranho, de Paulo Leminski, servem como ponto de análise da outridade, que se constitui no deslocamento do ser para o próprio interior. Ao abandonar suas condições do senso comum, o homem encontra na poesia a possibilidade de identificar sentidos que muitas vezes são indizíveis no nível da linguagem. A outridade dura o instante suficiente para captar tais sentidos e causar a surpresa que resulta a estupefação do óbvio, do evidente. Trata-se de um estudo teórico bibliográfico que corresponde à abordagem analítica centrada na outridade. As considerações finais revelam o trânsito do eu lírico no trajeto do deslocamento para a outridade e seu retorno às condições cotidianas. $\mathrm{O}$ termo outridade é empregado por Octávio Paz na obra O arco e a lira para designar o "outro" no ser humano, ou seja, ele mesmo; esse "outro" que causa estranheza a si mesmo e que questiona a própria identidade, primeiro pela repulsa, em seguida pela fascinação e, por última, pela vertigem. O “outro" que também é "eu", é o duplo tentando se capturar, mas que escapa, dando sentido à solidão.
\end{abstract}

Palavras-chave: Paulo Leminski. Outridade. Poesia.

\section{ABSTRACT}

Poetic cutouts of Paulo Leminski's The Ex-Stranger, serve as a point of analysis of the otherness, which is constituted by the displacement of the being into the interior. By abandoning his conditions of common sense, mankind finds in poetry the possibility of identifying meanings that are often unspeakable at the level of language. The otherness lasts the moment sufficient to capture these senses and cause the surprise that results in the stupefaction of the obvious, of the obvious. This is a theoretical bibliographical study that corresponds to the analytical approach centered on the otherness. The final considerations reveal the transit of the lyrical self in the path of displacement for otherness and its return to everyday conditions. The term otherness is used by Octavio Paz in the work The bow and the lyre to designate the "other" in the human being, that is, himself; this "other" that causes self-strangeness and questions one's identity, first by revulsion, then by fascination and, lastly, by vertigo. The "other" who is also "I", is the double trying to capture but that escapes, giving sense to the solitude.

Keywords: Paulo Leminski. Outridade. Poetry.

\section{RESUMEN}

Recortes poéticos de la obra El ex-estraño, de Paulo Leminski, siervem como base de revisión la alteridad, que es la desplazamiento de ser para la proprio interior. Para dejar sus condiciones de sentido común, la hombre hallazgos en poesia la posibilidad de identificar sentidos que muchas veces son indecibles em nivel del linguaje. La alteridad dura el instante suficiente para captar tales sentidos y causar la sorpresa que resulta la estupefacción de lo óbvio, del evidente. Se trata de un estudio teórico bibliográfico que corresponde al enfoque analítico enfocado en alteridade. Las consideraciones finales revelan el tránsito del yo lírico en la trayectoria del desplazamiento para la alteridad y su retorno a las condiciones cotidianas. La expresión alteridad es empleada por Octávio Paz em la obra El arco y la lira para designar al "otro" en el ser humano, o sea, él mismo; esse "otro" que causa extrañeza a sí mismo y que cuestiona la propria identidad, primero por la repulsa, depués por la fascinacion y, por último, por el vértigo. El "otro" que también es "yo", es el doble tratando de se capturan pero que escapa, dando sentido a la soledad.

Palabras clave: Paulo Leminski. Alteridad. Poesía. 


\section{Considerações iniciais}

Na obra O arco e a lira, Octavio Paz (1982), apresenta duas modalidades de outridade: o Outro enquanto criador/ poeta e, o outro enquanto leitor/receptor da expressão poética. Não se trata de alteridade ou mobilidade de identidades do ser, mas sim, do espanto diante da poesia que conduz ao regresso no próprio interior revivendo o real e transcendendo os sentidos. Nesse deslocamento para o Outro/outro, o ser encontra na poesia o que a linguagem lógica e racional do senso comum não consegue: a expressão dos sentidos mais recônditos.

É no campo poético, e somente no campo poético, que os contrários fazem as pazes e se tornam unos, que as palavras se volvem plurais, ofertando um leque de possibilidades sem distanciar-se da unidade de sentidos.

Neste contexto, este estudo pretende percorrer alguns poemas da obra $O$ ex-estranho, do paranaense Paulo Leminski, com o objetivo de identificar possibilidades de deslocamento do eu lírico para a outridade.

Paulo Leminski (1944-1989) é de Curitiba, estado do Paraná, dedicou-se a diversas áreas: prosa, poesia, tradução, publicidade, quadrinhos, artes gráficas, televisão e música popular. Suas publicações compreendem o romance Catatau (1975), a obra poética Caprichos e relaxos (1983), o romance Agora é que são elas (1984), a tradução de Giacomo Joyce, de James Joyce (1985), a tradução de Sol e Aço, de Yukio Mishima (1985), a obra poética La vie em close (1991), a obra em prosa Metamorfose (1994) e a obra poética Winterverno (1994).

$O$ ex-estranho, organizado pela esposa Alice Ruiz e pela filha Áurea Leminski, constitui uma seleção dos últimos poemas inéditos do polaco Paulo Leminski, alguns visivelmente inacabados. O termo "o ex-estranho" aparece duas vezes em seu livro La Vie em Close. É inegável que sua obra faz reviver diariamente e cada vez mais intensamente o paranaense que ao passar do tempo desperta a curiosidade de um público diverso e curioso.

Décio Pignatari ${ }^{1}$, em sua obra $O$ que é comunicação poética (2005, p.9), expõe que "a poesia [...] é a menos consumida de todas as artes, embora pareça ser a mais praticada (muitas vezes, às escondidas)". Talvez essa proposição explique porque a grande maioria dos poetas viveu em dificuldades financeiras, e que os louros somente foram reconhecidos e colhidos postumamente por familiares.

Com Paulo Leminski não foi diferente. Segundo relata Domingos Pellegrini, na obra Passeando por Leminski (2013), Leminski enfrentava dificuldades inclusive para

Paulo Leminski foi admirador dos concretistas Augusto/Haroldo de Campos e Décio Pignatari (PELLEGRINI, 2013). manter a família e, além disso, sua dependência alcoólica tomou-lhe a vida:

Nos últimos tempos eu não aguentava mais encontrar o polaco, para não ver como se matava, no entanto coerente com sua visão romântica de mártir poético, aprisionado pelo álcool, mas visando uma ressurreição artística (PELLEGRINI, 2013, p. 159-160).

Paulo Leminski dedicou-se ao concretismo e às vanguardas dos anos de 1940 e 1960 . Com apenas 20 e poucos anos, ministrava palestras na Biblioteca Pública de Curitiba. Ao longo do tempo, além de concretista na poesia, produziu prosa radical. No início dos anos 1980 discutia, por meio de cartas com muitas pessoas, os movimentos Pororoca e Tropicalismo.

O desafio em desvendar a outridade na expressão poética leminskiana desperta-se na medida em que se reconhece um observador atento a tudo, porém sem se comover, alguém que transita entre o senso comum e recolhe dali o alimento para toda a sua produção ao ceder espaço para seu Outro, voltando-se para si mesmo e levando consigo o leitor que, estupefato, se reconhece e identifica o que a linguagem sistematizada não dá conta: expressar os sentidos interiores, como define Domingos Pellegrini (2013, p. 126) ao referir-se a Paulo Leminski: "Sua visão mantém sempre essa sensação de descoberta e espanto diante da vida".

A partir do método analítico, os aspectos metodológicos compreendem um aparato teórico e bibliográfico, que subsidia a fortuna crítica e teórica sobre Paulo Leminski e suas produções artísticas recortadas para este estudo, compreendendo estudiosos como: Octavio Paz ( $O$ arco e a lira, 1982), Domingos Pellegrini (Passeando por Leminski, 2013) e Décio Pignatari (O que é comunicação poética, 2005). O arco e a lira reflete sobre o significado do poema, sua estrutura e importância no mundo ao longo do tempo; a obra se constitui na busca de respostas para as seguintes perguntas: Há um dizer poético? O que dizem os poemas? E como se comunica esse dizer? Passeando por Leminski é um livro de memórias que relata momentos de 17 anos de amizade entre Domingos Pellegrini e Paulo Leminski. O que é comunicação poética refere-se à linguagem criada e recriada pelo poeta a partir do som e da forma das palavras resultando na criação poética que suscita inesgotável fonte de imagens e sensibilidades.

\section{A linguagem poética}

Cada palavra possui vários significados mais ou menos conexos entre si. Cada um se ordena e significa de acordo com o lugar que ocupa na oração, fixando-se em uma única direção significante. Na poesia, essa pluralidade de significados não desaparece nem mesmo 
quando reúne contrários ou díspares, sem excluir as possibilidades primárias ou secundárias, conservando a unidade textual.

Pignatari (2005, p. 10), lembra que a "poesia é a arte do anticonsumo. A palavra 'poeta' vem do grego 'poietes $=$ aquele que faz'. Faz o quê? Faz linguagem. E aqui está a fonte principal do mistério". Na poesia há uma enunciação dos contrários violando a ordem lógica e racional do senso comum: "o poema não diz o que é e sim o que poderia ser" (PAZ, 1982, p. 120).

O poema é um ser de linguagem. O poeta faz linguagem, fazendo poema. Está sempre criando e recriando a linguagem. Vale dizer: está sempre criando o mundo. Para ele, a linguagem é um ser vivo (PIGNATARI, 2005, p. 11).

O poema é linguagem. Mas a linguagem está condenada à incapacidade de expressar o mundo. Sim, cada palavra tem seu valor, mas como bem lembra Paz (1982, p. 128): "O valor das palavras reside no sentido que ocultam” ou, como já dizia Paulo Leminski (2009, p. 36) "ouça bem o que não digo". Os sentidos se formam para além dos objetos dizíveis, até mesmo no silêncio. "Para o poeta, mergulhar na vida e na linguagem é (quase) a mesma coisa" (PIGNATARI, 2005, p. 11). Um poema parece falar de tudo e de nada, ao mesmo tempo, sem se esgotar. Embora seja um ser concreto da linguagem, o poema é o mais abstrato dos seres. Por mais que seja explicado, a explicação nunca poderá substituí-lo.

[...] as palavras podem ser explicadas pelas palavras. Toda frase quer dizer algo que pode ser dito ou explicado por outra frase. [...] ou seja: um dizer que se pode dizer de outra maneira (PAZ, 1982, p. 133).

A poesia é a expressão do indizível e, a linguagem é apenas "significado: sentido disto ou daquilo" (PAZ, 1982, p. 129). A linguagem representa a realidade recriando-a, ao passo que a poesia apresenta, sem recriá-la. A poesia penetra, estando ou sendo a realidade: "O poeta não quer dizer: diz. Orações e frases são meios" (PAZ, 1982, p. 134). O sentido do poema se encerra no próprio poema. A linguagem volta-se sobre si mesma: eis sua função poética.

O título do poema "Invernáculo", de Paulo Leminski, composto da palavra "vernáculo" acompanhada do sufixo “in" anuncia de antemão que o texto poético irá tratar de uma língua que não é padrão. A linguagem poética que segue apresenta os termos "língua", "sentido", "palavra", "digo", "minto", "falo", "dialeto" e "frase", funcionando como mecanismos do eu lírico para expressar que se apropriou de uma língua como ferramenta, uma língua que é comum a todos e não somente a ele, para expressar, inclusive, a mobilidade dos sentidos das palavras:
Invernáculo

(3)

Esta língua não é minha, qualquer um percebe.

Quando o sentido caminha,

a palavra permanece.

Quem sabe mal digo mentiras,

vai ver que só minto verdades.

Assim me falo, eu, mínima,

quem sabe, eu sinto, mal sabe.

Esta não é minha língua.

A língua que eu falo trava

uma canção longínqua,

a voz, além, nem palavra.

$\mathrm{O}$ dialeto que se usa

à margem esquerda da frase,

eis a fala que me lusa,

eu, meio, eu dentro, eu, quase

(LEMINSKI, 2009, p. 21).

Uma das principais características da expressão poética de Paulo Leminski são os paradoxos marcando o livre trânsito entre os opostos: "Quem sabe mal digo mentiras/ vai ver que só minto verdades.” E não há obrigação em dizer a verdade, mesmo quando enuncia realidades que possuem verdades. Contudo, essa verdade somente é válida dentro do seu próprio universo: nos versos da poesia. Até mesmo quando revela algo sobre o mundo ou sobre o íntimo do homem de um modo que pareça um disparate, revela de fato, ainda que por meio de um contrassenso, um dizer poético que encerra um sentido com algum fundamento objetivo. De fato, "as coisas possuem um sentido. [...] À semelhança da percepção comum, a imagem poética reproduz a pluralidade da realidade e, ao mesmo tempo, outorga-lhe unidade" (PAZ, 1982, p. 131). É na unidade do poema "Invernáculo" que o receptor é conduzido à reflexão da língua, com seus dialetos e variações diferenciando-a da língua portuguesa de Portugal: "eis a fala que me lusa". Embora o eu lírico tenha negado inicialmente a língua que utiliza, é nos últimos versos que se reconcilia com tal inquietude e confessa que é esta a ferramenta que domina para expressar-se "eu, meio, eu dentro, eu, quase."

A poesia não descreve os objetos, coloca-os diante do receptor. O verso poético "evoca, ressuscita, desperta, recria [...] não representa; apresenta. Recria, revive nossa experiência do real" (PAZ, 1982, p. 132). Dito de outro modo: "O poema nos faz recordar o que esquecemos: o que somos realmente" (PAZ, 1982, p. 133).

Já disse de nós.

Já disse de mim. Já disse do mundo.

Já disse agora, eu que já disse nunca.

Todo mundo sabe, eu já disse muito. 
Tenho a impressão

que já disse tudo.

E tudo foi tão de repente.

(LEMINSKI, 2009, p. 22).

Nesse poema, sem título, o receptor é convidado a recriar e a reviver o momento, com isso, regressa ao próprio interior. O poema não é uma forma literária, mas o ponto de encontro entre a poesia e o homem e lugar de diferenças e reconciliações: "A ambiguidade da realidade, tal como a apreendemos no momento da percepção: imediata, contraditória, plural e, não obstante, possuidora de um sentido recôndito" (PAZ, 1982, p. 133). $\mathrm{O}$ eu lírico enumera tudo o que já disse, mesmo sem de fato dizer, deixando as entrelinhas carregadas de sentido ao bel prazer do receptor: "Já disse de nós. / Já disse de mim. / Já disse do mundo"; reconhece suas contradições internas: "já disse agora, / eu que já disse nunca" e conclui que "já disse muito". A sensação interior ocupa seu lugar de primeiro plano e confirma que o eu lírico não tem mais nada a dizer, apenas a sentir que "tudo foi tão de repente", que em um instante cabe toda uma vida.

O sentido da poesia não se pode dizer com outras palavras, pois a poesia explica-se por si mesma e, sua linguagem plural significa de modo particular a cada receptor, de acordo com seus conhecimentos de mundo. O sentido poético é apreendido e as palavras, muitas vezes, não dão conta de expressarem/interpretarem tal sentido, devido à mobilidade significante da linguagem: "já disse muito" e lembrando que "nem tudo que a gente pensa, consegue expressar!" (LEMINSKI, 2009 apud PELLEGRINI, 2013, p. 72).

É por isso que Paz (1982) diz que o poema transcende a linguagem; o poema é a linguagem e alguma coisa a mais.

O poema é linguagem em tensão: em extremo de ser e em ser até o extremo. Extremos da palavra e palavras extremas, voltadas sobre suas próprias entranhas, mostrando o reverso da fala: o silêncio a e nãosignificação (PAZ, 1982, p. 135).

A poesia é o lugar onde os opostos se reconciliam descobrindo semelhanças ou aproximando realidades contrárias, muitas vezes a partir de uma impossibilidade lógica e até mesmo linguística, produzindo uma nova realidade. Trata-se das comparações. No poema "a linguagem, voltada sobre si mesma, diz o que por natureza parecia lhe escapar. $\mathrm{O}$ dizer poético diz o indizível" (PAZ, 1982, p. 136). O dizer poético constitui a "outra voz", onde os opostos se fundem, em que o homem se torna outro para, depois, reconciliar-se consigo mesmo.

\section{A Outridade poética}

O homem se distingue dos demais e também de outros seres vivos pela linguagem, pela maneira de ser e agir, cuja atuação no mundo acarreta mudanças. O homem renasce a cada instante a partir da mudança que opera em si mesmo. De acordo com Paz (1982), a poesia surge para resolver algo do ser com sua Outridade, seu Outro eu.

No poema "Sei lá", de Paulo Leminski, é evidente esta luta inquietante que se trava com seu Outro eu, na indecisão de percorrer o deslocamento que culminará na outridade:

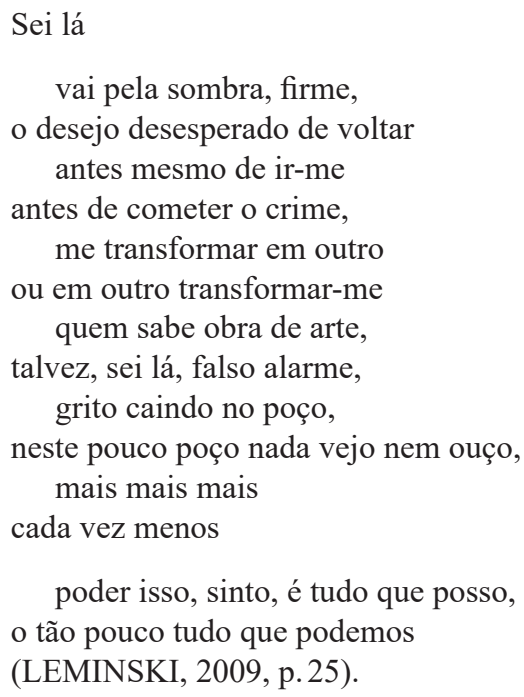

No encontro com a expressão poética, o receptor pode ser surpreendido assombrosamente ao perceber uma realidade cotidiana que de repente é revelada como nunca foi vista. Ocorre o susto ao deparar-se com a própria realidade, com o encontro diante da identidade de seu próprio ser. "O poema se realiza na participação, que nada mais é que a recriação do instante original. Assim, o exame do poema nos leva ao exame da experiência poética" (PAZ, 1982). Para o autor, a poesia é a expressão do espanto no encontro do eu com a Outridade: "o Outro é algo que não é como nós, um ser que é também um não ser. E a primeira coisa que sua presença desperta é a estupefação" (PAZ, 1982, p. 156). A estupefação diante do simples cotidiano:

o barulho do serrote o barulho de quem lava roupa parecem o choro de quem chora uma vida pouca parece até que está na hora de levantar

e ver que a vida nunca vai ser outra (LEMINSKI, 2009, p. 27). 
Este poema de Paulo Leminski, parte justamente de elementos das atividades do senso comum serrar, lavar roupa e chorar. No entanto, conduz o receptor a apurar os sentidos e transcender o ato destas ações rotineiras, detendo-se no som do serrote e da lavagem da roupa, comparando com o choro, a tristeza de alguém que tem a certeza que o próprio viver é algo a mais do que estas ações. Há um auge na expressão poética: "parece até que está na hora / de levantar", sugerindo o deslocamento do receptor para a outridade, o que se desfaz rapidamente quando o eu lírico o traz novamente e lembra "que a vida / nunca vai ser outra".

A expressão poética está ligada ao sagrado, que por sua vez concatena o ritual. O que leva ao sagrado é o momento em que o ser se perde da realidade lógica e cotidiana, acontecendo o espanto, o qual recupera o tempo original.

O sagrado transcende a sexualidade e as instituições sociais em que se cristaliza. É erotismo, mas é algo que ultrapassa o impulso sexual; é um fenômeno social, mas é outra coisa. O sagrado nos escapa. Ao tentarmos prendê-lo, percebemos que ele tem sua origem em algo anterior que se confunde com nosso ser. Assim ocorre com o amor e a poesia (PAZ, 1982, p. 164).

Quando acontece o amor, o sujeito deixa de ser ele mesmo, transcende. O poético realiza a percepção da Outridade no sujeito, seja o poeta, seja o receptor da expressão poética. É por meio do estranhamento, do espanto, que a poesia escancara a Outridade. O ser deixa de ser quem é pelo espanto que surge da poesia. "A revelação [...] transforma-se num abrir-se do homem para si mesmo" (PAZ, 1982, p. 170).

O poema a seguir sugere esta revelação poética que orienta o receptor a voltar-se inquieto para o próprio interior, concedendo vez para a outridade que vasculha suas identidades (menino de dúvidas ou homem de fé?) e volta a sim com mais um paradoxo leminskiano: a certeza de que tudo é incerto:

nunca sei ao certo

se sou um menino de dúvidas

ou um homem de fé

certezas o vento leva

só dúvidas continuam de pé

(LEMINSKI, 2009, p. 38).

Amor, alegria, angústia, aborrecimento, nostalgia, solidão, entusiasmo, ira e outros sentimentos são indizíveis, mas somente passam a ser estados poéticos quando motivam o poeta. Depois de concebida a expressão poética, o poeta encontra-se na solidão: "só dúvidas continuam de pé”.
O leitor constitui o outro que dará continuidade da poesia como recriação, desprendendo-se de si mesmo para penetrar no "outro si mesmo", até então desconhecido ou ignorado (PAZ, 1982). Ao embrenhar-se em si mesmo, transita entre os contrários em uma reflexão que alcança níveis filosóficos:

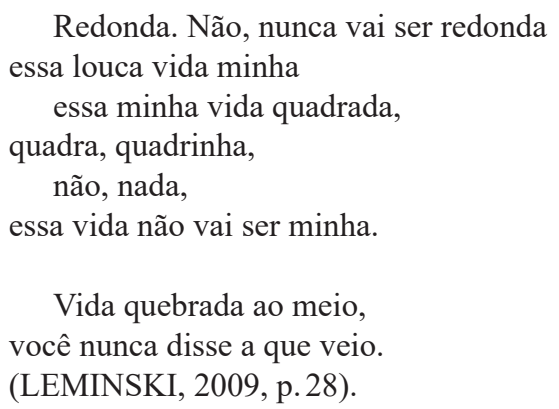

O ser depara-se fora da bolha da ilusão de um viver regrado, tranquilo e certeiro, percebe, estupefato, que é um homem que muda, que erra, aprende e se transforma, que significa o próprio meio e justamente por isso sua vida jamais será de fato sua, pois agrega o contexto. Tratase de um olhar do outro sobre si mesmo e o retorno ao ser comum permanecendo a certeza de não saber do futuro: "você nunca disse a que veio".

Na perspectiva de Paz (1982), a outridade constitui um fenômeno que se dá em dois eixos: primeiro no próprio poeta, na criação artística, quando seu Outro, com o maiúsculo, abandona as condições cotidianas da realidade para, na surpresa do estranhamento, revelar o indizível na expressão poética.

$\mathrm{O}$ ato de escrever encerra, como primeiro movimento, um desligar-se do mundo, algo como lançar-se no vazio. O poeta já está sozinho. Tudo que um momento antes era seu mundo cotidiano, suas preocupações habituais, desaparece. Se o poeta quer realmente escrever e não apenas cumprir uma vaga cerimônia literária, seu ato leva-o a se desligar do mundo e a pôlo inteiro - sem exclusão de si mesmo - em interdição (PAZ, 1982, p. 215).

Então o poeta nomeia a realidade do mundo com os vocábulos prevalecendo o silêncio anterior às palavras. Surge a poesia por meio da linguagem. A linguagem é social e a literatura somente assume tal aspecto se tiver o leitor para manuseá-la. Nesse sentido, tem-se o segundo eixo proposto por Paz (1982), que corresponde ao leitor, o outro ser, outro com "o" minúsculo, responsável pela recriação da poesia na sua recepção.

É este leitor que, deslocado para a outridade, mobilizará seus conhecimentos de mundo ao deter-se na expressão poética, motivando diversos significados para cada palavra, como no poema a seguir: 
acordei e me olhei no espelho

ainda a tempo de ver

meu sonho virar pesadelo

(LEMINSKI, 2009, p. 54).

No primeiro verso do poema, encontra-se uma ação totalmente cotidiana: "acordei e me olhei no espelho", no entanto, a frase está aberta a outras interpretações, ampliando seus horizontes a partir de possibilidades de que não seja um acordar matutino, não há informações concretas sobre isso, por isso a leitura pode seguir para outro viés: um acordar que remete ao visualizar novas perspectivas. O deslocamento para a outridade se confirma diante do espelho e, é a partir deste objeto que o leitor aguçará ainda mais a multiplicidade de significados, pois o espelho remete a aspectos simbólicos de observar o reflexo; reflexo este que devolverá a realidade em verdade e sinceridade, a qual em um lapso de instantes faz o ser deixar a outridade e voltar a si: "ainda a tempo de ver / meu sonho virar pesadelo".

A recepção da poesia se dá pelas palavras, as quais não são nem do Outro/poeta nem do outro/leitor, pois são constitutivas do homem, da mesma forma que constituem a outridade. Sobre a linguagem de Paulo Leminski, Domingos Pellegrini (2013, p. 125) comenta que há uma duplicidade evidente, nos arranjos das palavras: "Essa recusa a escrever de forma usual, essa ojeriza ao lugar comum, esse pavor do chavão, essa procura rigorosa da expressão inovadora, sem no entanto abrir mão da comunicação, torna sua linguagem única".

A repulsa ao comum é exatamente o ponto de partida da expressão poética, o terreno fértil que servirá a um trabalho santo do saber fazer, que transcende o óbvio e revela o que a linguagem sistematizada do homem não dá conta: é o trabalho do poeta em revelar o novo a partir da combinação do que é evidente, em uma reflexão metalinguística:

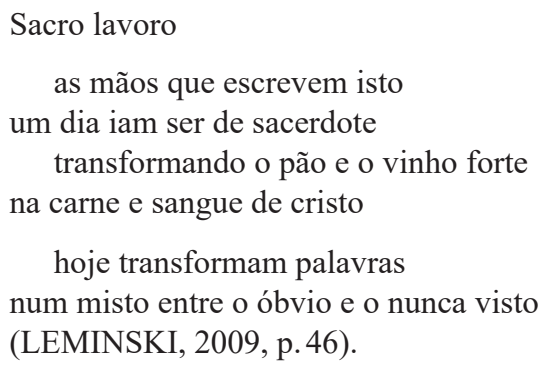

Sabe-se que Paulo Leminski, aos quatorze anos, foi para o Mosteiro de São Bento, em São Paulo, ficando lá por um ano. Esse período influenciou alguns poemas da obra $O$ ex-estranho que revelam palavras em latim (Sacro lavoro) e conteúdos religiosos (PELLEGRINI, 2013).
Observa-se que o único poema concreto da obra aparece em formato de uma cruz:

re
mortas
eras remotas
mil
$\&$
uma
portas
(LEMINSKI, 2009, p. 58).

É comum encontrar na obra poética de Leminski trocadilhos. Nesse caso há uma inversão de letras: re / mortas / eras / remotas, formando os três versos iniciais e sugerindo a recorrência da morte longínqua, um adiamento da morte em "mil/ \& / uma/ portas", ocorrendo uma intertextualidade com o livro árabe Mil e uma noites, onde Xerazade fora entregue para ser noiva do rei e a cada noite contava-lhe histórias, as quais dava continuidade na noite seguinte deixando o rei curioso, adiando assim a própria morte.

A atuação do leitor sugere, a partir do signo porta, um novo deslocamento para a outridade, na perspectiva das significações que assumem a palavra porta: é o símbolo do ingresso, do secreto e do misterioso que há por trás dela. Em muitas culturas, atravessar uma porta é o símbolo de um rito de passagem de um estágio da vida para o próximo, da mesma forma que tais portas são defendidas por figuras de guardiães. A porta é a parte mais significativa da casa. Ela se abre e se fecha, batese, tranca-se. Quando é atravessada para entrar ou sair, tem-se acesso a condições diferentes de existência, a um outro estado de consciência, e por isso ela conduz a outras pessoas, a uma outra atmosfera (BIEDERMANN, 1993). Dessa forma, as mil e uma portas apontadas no poema, indicam o trajeto para o deslocamento que leva à outridade, o que inicia inclusive no plano do conteúdo poético com a transformação das letras em novas palavras e novos sentidos, continuando pela intertextualidade.

A linguagem, as palavras, ao serem transpostas para a poesia, são acompanhadas de ritmos, de adjetivos e outros elementos que as fazem ser justamente diferentes do cotidiano. Por isso, as palavras do poeta são e não são dele e revelam justamente as vozes do mundo com novo sentido.

A palavra poética é a revelação de nossa condição original porque por ela o homem, na realidade, se nomeia outro, e assim ele é ao mesmo tempo este e aquele, ele mesmo e o outro.

O poema faz transparecer nossa condição porque em seu seio a palavra se torna algo exclusivo do poeta, sem por isso deixar de ser do mundo, isto é, sem deixar de ser palavra (PAZ, 1982, p. 217). 
A palavra torna-se, assim, a ponte que une o homem com sua outridade. Este homem que é mudança contínua, que "se realiza ou se completa quando se torna outro" (PAZ, 1982, p. 217). A outridade representa os homens em um todo, inseridos em um mundo racional e irracional. $\mathrm{Na}$ visão de Paulo Leminski: "a vida é um acidente contínuo sujeito a virar o direito pelo avesso!" (PELLEGRINI, 2013, p. 40).

Essa transformação do ser indica que sua vida está em constante movimento. Esse movimento é identificado na disposição gráfica do poema "Johnny B. Good" e em seu conteúdo:

\author{
Johnny B. Good \\ tem vezes que tenho vontade \\ de que nada mude \\ vou ver \\ mudar é tudo que pude \\ (LEMINSKI, 2009, p. 50).
}

Embora o eu lírico pareça criticar a constante mudança do mundo, reconhece que a mesma é inevitável, constituindo a essência da realidade. Conclui que ser uno já não é possível e é exatamente essa passagem para a outridade que lhe permite mudar: "mudar é tudo que pude".

\section{Considerações finais}

Ao percorrer alguns poemas da obra $O$ ex-estranho, de Paulo Leminski, foi possível apontar possibilidades de deslocamento do eu lírico para a Outridade. Sendo o eu lírico o sujeito do discurso que faz das palavras as ferramentas para a construção poética, a qual revela essa transformação, a busca pela outridade, ou seja, a procura por si mesmo representado e diluído no nível da linguagem.

O poema abriga a tensão entre o sujeito e o outro, entre as palavras e a realidade, encontrando o solipsismo que dissolve as contradições, fazendo o homem renascer, recriando-o e assumindo sua verdadeira condição que é a totalidade de vida e morte no mesmo instante.

Instantes breves, mas suficientes para que o ser se desloque à outridade e retorne a si, tal como no poema "Invernáculo" quando, entre verdades e mentiras busca expressar sua poesia por meio de uma língua que não é sua, mas que é por meio dessa língua que materializa a condição poética na outridade.

Dizer tudo sobre si mesmo implica uma viagem interior, a busca e a análise do que é e do que sente, é falar de si e do mundo. Para isso, o eu lírico abandona suas condições habituais e leva consigo o receptor, avaliando momentos, anos de vivência e conclui que não sabe de nada, apenas sente.
Entende-se que os poemas abordados são passíveis de novas investidas de leituras, na perspectiva da pluralidade poética. Conclui-se que a outridade é um fenômeno recorrente poemas abordados bem como em outras criações poéticas de Paulo Leminski, o que permite reconhecer que o viés deste estudo encontra recepção na ampliação de análise sobre outros textos agregando novos elementos.

\section{Referências}

BIEDERMANN, Hans. Dicionário ilustrado de símbolos. Trad. Glória Paschoal de Camargo. São Paulo: Companhia Melhoramentos, 1993.

LEMINSKI, Paulo. O ex-estranho. Org. Alice Ruiz S. e Áurea Leminski. 3. ed. São Paulo: Iluminuras, 2009.

PAZ, Octavio. O arco e a lira. Trad. Olga Savary. Rio de Janeiro: Nova Fronteira, 1982.

PELLEGRINI, Domingos. Passeando por Paulo Leminski. Curitiba, 2013. Disponível em: https://pt.scribd.com/ doc/176716911/Passeando-Por-Leminski-De-DomingosPellegrini. Acesso: 19 maio 2018. https://doi.org/10.20396/ remate.v35i2.8645200

PIGNATARI, Décio. O que é comunicação poética. 8 ed. Cotia, SP: Ateliê Editorial, 2005.

Recebido em: 29/5/2018.

Aprovado em: 26/3/2019.

Publicado em: 21/06/2019.

Autoras:

ADRIANE CHERPINSKI

Doutoranda em Letras (UEM). Mestre em Letras na área de concentração em Interfaces entre Língua e Literatura, pela Universidade Estadual do Centro-Oeste do Paraná (UNICENTRO) (2013). Graduada em Letras Português e suas Literaturas (2006) pela UNICENTRO Universidade Estadual do Centro Oeste, pós-graduada em Literatura e Contemporaneidade (2008) e em Gestão Escolar (2011) também pela UNICENTRO. Dedica-se aos estudos da ecocrítica, especialmente no campo da literatura brasileira, com ênfase em Clarice Lispector.

Orcid: https://orcid.org/0000-0002-5518-6215

E-mail: adriane.cherpinski@hotmail.com

EVELY VÂNIA LIBANORI

Professora do Departamento de Teorias Linguísticas e Literárias da Universidade Estadual de Maringá desde 1997. Fiz mestrado e doutorado na UNESP/Assis. Em agosto de 2018 conclui o estágio de Pós-Doutoramento em Crítica Cultural, na UEL/PR. Desenvolvi a pesquisa Ética e Poética Animal em Clarice Lispector;. Na Graduação trabalho Literatura Brasileira - Narrativa, e Práticas Metodológicas em Educação Literária. Na Pós-Graduação trabalho com romances latinoamericanos e com o referencial teórico referente ao Existencialismo, Ecocrítica, Identidade humana e animal, Ética Animal. Estou à frente do GAIA (Grupo de Atividades Interdisciplinares sobre os Animais), grupo de pesquisa cadastrado no CNPq e que estuda libertação animal, ética animal, veganismo. Sou coordenadora adjunta do Programa de Pós-graduação em Letras (PLE) desde setembro de 2012 até o presente momento. Oriento pesquisas na Graduação e na Pós-Graduação relacionadas a esses campos de estudo/conhecimento: Representação de Identidades na Literatura, Ética Animal, Poética Animal, Representação Animal na Literatura, Clarice Lispector, Existencialismo. Em maio de 2014, lancei o livro de crônicas abolicionistas animalistas Nós, Animais. Orcid: https://orcid.org/0000-0001-5964-6584

E-mail: lieveorama@gmail.com

Centro de Ciências Humanas, Letras e Artes $(\mathrm{CCH})$

Av. Colombo, 5790, bloco G34 - Caixa Postal

87020-900, Maringá, PR, Brasil 